\title{
HOLY QURAN RECITATION OF SURAH AL-MULK AND AL-HASYR ON DECREASING ANXIETY IN MEDICAL STUDENTS
}

\author{
Kaima Ishmata Rianti ${ }^{1}$, Indri Seta Septadina ${ }^{2 *}$, Bintang Arroyantri Prananjaya ${ }^{3}$ \\ ${ }^{1}$ Faculty of Medicine, Universitas Sriwijaya, Palembang \\ ${ }^{2}$ Departement of Anatomy, Faculty of Medicine, Universitas Sriwijaya, Palembang \\ ${ }^{3}$ Departement of Psychiatry , Faculty of Medicine, Universitas Sriwijaya, Palembang
}

\begin{abstract}
Anxiety is a feeling of discomfort, worry about something unclear and accompanied by autonomic symptoms. Holy Quran recitation therapy is one of the anxiety complementary therapies. This study is aimed to analyze the effect of the murottal Quran Surah Al-Mulk and Al-Hasyr on the anxiety of medical students of Universitas Sriwijaya. This research is a quasi-experimental study with a cross-sectional approach and one group pre-post test design that was conducted from July to December 2020 at home via Zoom meeting application. Samples were collected based on simple random sampling rocedure. The data was collected in this study is primary data based on Beck Anxiety Inventory (BAI) questionnaire before and after receiving the Quran recitation surah Al-Mulk and Al-Hasyr for 7 consecutive days. The data was analyzed with Shapiro-Wilk normality test and Paired t-test or Wilcoxon test using SPSS device. The Wilcoxon test results showed significant results of murottal Al-Qur'an surah Al-Mulk and Al-Hasyr on anxiety $(\mathrm{p}=0.000)$. There is an effect of holy Quran recitation of surah Al-Mulk and Al-Hasyr on anxiety among medical students of Universitas Sriwijaya.
\end{abstract}

Keywords: anxiety, quran, BAI, medical student 


\section{INTRODUCTION}

Anxiety is a subjective feeling of discomfort and worry about unpleasant situation that accompanied by autonomic symptoms(Sadock et al., 2007). Anxiety causes changes to the three body systems: cognitive, physical and behavioural(Rector et al., 2011). Most of medical students were reported to have anxiety and often associated with symptomatic disease(Ikhsan et al., 2020; Wijaya et al., 2019). Generally, anxiety among medical students was caused by interpersonal problems, high academic pressure, sleep deprivation, low self-evaluation, and lack of social support(Mao et al., 2019).

Nonpharmacological approaches has less adverse effects and can be applied for longer period of time than pharmacological therapy(Chandler et al., 2019). Complementary therapy is a different form of therapy of medicine in general and was known to have high quality, safety and effectiveness based on biomedical science(Holownia, 2011; Kemenkes, 2007).

Holy Quran recitation therapy is one of the anxiety complementary therapies. Quran is the comprehensive word of Allah that was spread by the Prophet Muhammad and was written in the Mushaf start from Surah Al-Fatihah to Surah An-Naas and conveyed to the Moslem community who read it as worship(Wahyuddin \& Saifulloh, 2013). Quran contains poetic content and rhythmic pronunciation. Therefore, it is comfortable to hear even to the non-Arabian and who rarely read Quran(Nakhavali \& Seyyedi, 2013).

A study performed by Heidari et al. had indicated that holy Quran recitation significantly reduced anxiety in nursing and emergencies students before exams(Heidari et al., 2014). Holy Quran recitation intervention group had a greater reduction in anxiety than the music intervention group(Ghiasi \& Keramat, 2018). Recitation of Quran produced alpha waves on electroencephalogram (EEG) that indicated someone is relaxed(Shekha et al., 2013). Among all surahs in Quran, Surah Al-Mulk and Al-Hasyr have been proven in producing alpha waves(Ismail \& Sharif, 2017).

The development of research related to anxiety complementary therapy as safe therapy is important. This study is aimed to analyze the effect of holy Quran recitation therapy of Surah Al-Mulk and Al-Hasyr on anxiety in medical students of Universitas Sriwijaya.

\section{METHODS}

This study was a quasi-experimental study with one group pre-post test design. The population consisted of all medical students of Universitas Sriwijaya batch 2017 who met the inclusion and exclusion criteria. The inclusion criteria were Moslem student, willingly 
to be research participant and fulfill the intervention schedule. While exclusion criteria were listening holy Quran recitation every day and taking anti-anxiety drugs. Samples in this study included 45 medical student based on simple random sampling procedure.

Beck Anxiety Inventory (BAI) questionnaire was given before the intervention as a pretest and after the intervention as a post-test. The intervention was performed on 1-7 December 2020 at home via Zoom meeting application due to the COVID-19 pandemic. Subject listened to the surah Al-Mulk and Al-Hasyr recitation by qori Mishary Rasyid Al'Afasy for 18 minutes a day in 7 consecutive days.

The data was analyzed using Statistical Package for the Social Sciences (SPSS) application version 25 . The analysis was carried out in the form of univariate analysis to determine anxiety before and after holy Quran intervention and bivariate analysis to determine differences in anxiety before and after holy Quran intervention. Saphiro-Wilk normality test was performed before analyzing differences in anxiety. Then the data were analyzed by Paired t-test or Wilcoxon test.

\section{RESULTS}

In this study, there were 45 participants who met the inclusion and exclusion criteria. Table 1 shows the proportion of minimal or normal anxiety level in the male participants was less $(22.2 \%)$ than women $(44.4 \%)$. The highest level of anxiety in male participants was at moderate level (44.4\%), while the highest level of anxiety in female participants was at the minimal level $(44.4 \%)$

Table 1. Participants in the Study of Gender Variable and Anxiety

\begin{tabular}{lccccc}
\hline \multirow{2}{*}{ Gender } & \multicolumn{3}{c}{ Anxiety level } \\
\cline { 2 - 7 } & $\begin{array}{c}\text { Minimal/ normal } \\
(\boldsymbol{\%})\end{array}$ & Mild (\%) & $\begin{array}{c}\text { Moderate } \\
(\boldsymbol{\%})\end{array}$ & Severe (\%) & $\mathbf{n}$ \\
\hline Man & 22,2 & 22,2 & 44,4 & 11,1 & 9 \\
\hline Woman & 44,4 & 33,3 & 13,9 & 8,3 & 36 \\
\hline \multicolumn{1}{c}{$\mathbf{n}$} & 18 & 14 & 9 & 4 & 45 \\
\hline
\end{tabular}

There were 18 students (40\%) who had minimal or normal anxiety level before receiving holy Quran intervention (see table 2), meanwhile others (60\%) had anxiety. After receiving the intervention, the number of participants with minimal or normal anxiety level increased into 39 students $(86.7 \%)$. This also indicated that anxiety of participants decreased from $60 \%$ to $13.3 \%$. 
Table 2. Frequency Distribution of Subject Based on Anxiety Before and After Surah AlMulk and Al-Hasyr Recitation Intervention

\begin{tabular}{|c|c|c|c|c|}
\hline \multirow{2}{*}{ Anxiety level } & \multicolumn{2}{|c|}{ Before Intervention } & \multicolumn{2}{|c|}{ After Intervention } \\
\hline & $\mathbf{f}$ & $\%$ & $\mathbf{f}$ & $\%$ \\
\hline Minimal/ normal (0-7) & 18 & 40 & 39 & 86,7 \\
\hline Mild (8-15) & 14 & 31,1 & 4 & 8,9 \\
\hline Moderate (16-25) & 9 & 20 & 1 & 2,2 \\
\hline Severe (26-63) & 4 & 8,9 & 1 & 2,2 \\
\hline $\mathbf{n}$ & 45 & 100 & 45 & 100 \\
\hline
\end{tabular}

The mean BAI score before getting the intervention was $11.49 \pm 9.324$ and the median value was $10(0 ; 48)$. The mean BAI score of the research participants after receiving the holy Quran recitation decreased to $4.93 \pm 6.910$ and the median value was $4(0 ; 43)$ (see table 3 ).

Tabel 3. BAI Score Distribution Before and After Surah Al-Mulk and Al-Hasyr Recitation Intervention

\begin{tabular}{ccccccc}
\hline & $\mathbf{n}$ & Mean & $\begin{array}{c}\text { Standard } \\
\text { deviation }\end{array}$ & Median & Min. & Max. \\
\hline Before intervention & 45 & 11,49 & 9,324 & 10 & 0 & 48 \\
\hline After intervention & 45 & 4,93 & 6,910 & 4 & 0 & 43 \\
\hline
\end{tabular}

Normality test was used before analyzing the statistical difference between BAI score of the particpants before and after holy Quran intervention. The normality test used was Shapiro-Wilk because the sample was less than 50. The normality test showed (see table 4) the $\mathrm{p}$ value before $(\mathrm{p}=0.000)$ and the $\mathrm{p}$ value after $(\mathrm{p}=0.000)$ were less than 0.05 , means that BAI score before and after the holy Quran recitation intervention is not normally distributed.

Tabel 4. Normality Test Result

\begin{tabular}{cccc}
\hline BAI score & n & Shapiro-Wilk & P value \\
\hline Before & 45 & 0,882 & 0,000 \\
\hline After & 45 & 0,574 & 0,000
\end{tabular}

Due to the abnormal distribution, BAI score before and after holy Quran recitation intervention were analyzed using Wilcoxon test (see table 5). The Wilcoxon test result showed $\mathrm{p}$ value $<0.05(\mathrm{p}=0.000)$, that means there was significant result between holy Quran recitation and anxiety. Therefore, holy Quran recitation affects subject anxiety.

Table 5. Comparison of Anxiety among Students with Quran Recitation

\begin{tabular}{cccc}
\hline BAI Score & n & Median (min;max) & p value \\
\hline Before & 45 & $10(0 ; 48)$ & $0,000^{*}$ \\
\hline After & 45 & $4(0 ; 43)$ & \\
\hline
\end{tabular}




\section{DISCUSSION}

In this study, the proportion of male participants who had anxiety was greater $(77.8 \%)$ than women $(55.6 \%)$. This result was different with the study conducted by Wijaya, Sugiharto and Zulkarnain that the proportion of anxiety in medical students batch 2013 of Universitas Sriwijaya was more common in female students (65.7\%) than male students (53.3\%)(Wijaya et al., 2019). Apriady, Yanis and Yulistini also reported in their study that anxiety symptoms were mostly found in female students $(50.81 \%)$ than male students $(38.27 \%)$. This condition was influenced by the instability of hormone regulation in women and made woman more sensitive in receiving stressors than men(Apriady et al., 2016). The difference of theory and previous study with this result was thought to be caused by imbalance in the number of male ( 9 students) and female (36 students) participants. Wijaya, Sugiharto and Zulkarnain stated in their study that there was no significant relationship between gender and anxiety(Wijaya et al., 2019).

Most participants of this study had anxiety before receiving Quran recitation intervention (60\%). This result was similar to study was performed by Wijaya, Sugiharto and Zulkarnain which found that $61.9 \%$ of medical students experience anxiety based on Hamilton Anxiety Rating Scale (HARS)(Wijaya et al., 2019). Nurrezki and Irawan also reported that $57.1 \%$ of medical students had anxiety based on Depression Anxiety Stress Scales (DASS)(Nurrezki \& Irawan, 2020). These studies showed high incidence of anxiety among medical students. This condition was thought to be caused by factors related to medical student anxiety. According to Mao et al., anxiety in medical students related to interpersonal problems, high pressure on academic obligations, low self-evaluation, poor sleep quality, and low motivation(Mao et al., 2019).

A decrease proportion of research participants who had anxiety from $60 \%$ to $13.3 \%$ indicates that some participants had decreased anxiety. In this study, there was a decrease mean of BAI scores when compared before and after receiving the intervention from mild (11.49 \pm $9.324)$ to minimal or normal $(4.93 \pm 6.910)$. The median level of BAI score also decreased from mild anxiety level $(10(0 ; 48))$ to minimal or normal level $(4(0 ; 43))$. In the study of Heidari, Shahbazi and Bahrami, it was found that mean apparent anxiety score measured by Spiel Berger anxiety in the intervention group was lower $(39.11 \pm 11.82)$ than the control group $(41 \pm$ 12.9852)(Heidari et al., 2014).

Not all participants in this study had decreasing anxiety. There was a negative BAI score difference on four participants, that means the participants had increased anxiety. One of the factors thought influences it was the cognitive and emotional state of a person. A negative cognitive and emotional state toward spirituality may affect their belief and feelings of closeness to God. Anxiety disorders may also be a factor of increased anxiety(Rosmarin \& Leidl, 2020). Other factor that may affect the increase in anxiety was the confounding variables that occur during this study, such as signal interference when using Zoom meeting application, uncomfortable environment, and other activities carried out during the study. 
Wilcoxon test on BAI score gave a value of $\mathrm{p}<0.05(\mathrm{p}=0.000)$, that means the anxiety and holy Quran Surah Al-Mulk and Al-Hasyr recitation intervention statistically significant. This means that holy Quran Surah Al-Mulk and Al-Hasyr recitation intervention has an effect on anxiety in the research participants. The results of this study are similar to Sari et al. who showed a significant anxiety score reduction in medical students based on HARS after receiving holy Quran surah Al-Mulk recitation for 14 days(Sari et al., 2019). Heidari, Shahbazi and Bahrami also reported a significant differences between the intervention group that was listened Quran and the control group ( $\mathrm{p}<0.05$ )(Heidari et al., 2014). Research by Idham and Ridha found that holy Quran intervention for two days decrease academic anxiety measured by modified academic anxiety scale(Idham \& Ridha, 2016).

The relationship between brain activity recorded by EEG and human emotions is unclear. However, there were several studies that found holy Quran recitation produces alpha waves that indicated someone is relaxed. Alpha waves on participants who listened to the holy Quran were higher than participants who listened to relaxation music(Al-Galal \& Alshaikhli, 2017). Neurotransmitters produced by auditory nerve pathways stimulate the primary auditory nerves and limbic cortex(Hall, 2011). Stimulation that was produced by music and relaxation rhythms such as holy Quran recitation suppresses amygdala activity which plays a role in reducing autonomic symptoms. This stimulation also stimulates the hypothalamus and it suppress the release of CRF and also play a role in suppressing amygdala activity(Shekha et al., 2013).

Quran has rhytmic recitation, poetic content and constant tempo and make it comfortable to hear even to the non-Arabian and who rarely read Quran(Nakhavali \& Seyyedi, 2013). Surah musabbihaat as surah Al-Hasyr has phrases that are full of rhetorical sentences and harmony in it sounds(Managheb \& Jafari, 2014). The uniqueness in content and rhythm makes holy Quran recitation as a sound therapy that is comfortable to listen to.

\section{CONCLUSION}

Based on this research, it can be concluded that there was an effect of the holy Quran recitation of Surah Al-Mulk and Al-Hasyr on anxiety $(\mathrm{p}<0.05)$ in medical students of Universitas Sriwijaya. It was found that there was a decrease in the proportion of participants who had anxiety from $60 \%$ to $13.3 \%$. There was also a decrease in the median BAI score from $10(0 ; 48)$ to $4(0 ; 43)$. 


\section{References}

Al-Galal, S. A., \& Alshaikhli, I. F. T. (2017). Analyzing Brainwaves While Listening To Quranic Recitation Compared With Listening To Music Based on EEG Signals. International Journal on Perceptive and Cognitive Computing, 3(1), 1-5. https://doi.org/10.31436/ijpcc.v3i1.43

Apriady, T., Yanis, A., \& Yulistini, Y. (2016). Prevalensi Ansietas Menjelang Ujian Tulis pada Mahasiswa Kedokteran Fk Unand Tahap Akademik. Jurnal Kesehatan Andalas, 5(3), 666-670. https://doi.org/10.25077/jka.v5i3.596

Chandler, S. K., Robins, J. L., \& Kinser, P. A. (2019). Nonpharmacologic interventions for the self-management of anxiety in Parkinson's disease: A comprehensive review. Behavioural Neurology, 2019. https://doi.org/10.1155/2019/8459579

Ghiasi, A., \& Keramat, A. (2018). The Effect of Listening to Holy Quran Recitation on Anxiety: A Systematic Review. Iranian Journal of Nursing and Midwifery Research, 23(6), 411-420.

Hall, J. E. (2011). Guyton dan Hall Buku Ajar Fisiologi Kedokteran (12th ed.). Saunders Elsevier.

Heidari, M., Shahbazi, S., \& Bahrami, A. (2014). Assess the effect of Quran on exam anxiety in nursing and ems students. 4(2), 51-56.

Holownia, P. (2011). Complementary medicine. Australian Family Physician, 40(4), 183.

Idham, A. F., \& Ridha, A. A. (2016). Apakah Mendengarkan Murottal Al-Quran Dapat Menurunkan Kecemasan Akademik Pada Mahasiswa? Intervensi Psikologi, 9(2), 141154.

Ikhsan, M. H., Murni, A. W., \& Rustam, E. R. (2020). Hubungan Depresi, Ansietas, dan Stres dengan Kejadian Sindrom Dispepsia pada Mahasiswa Tahun Pertama di Fakultas Kedokteran Universitas Andalas Sebelum dan Sesudah Ujian Blok. Jurnal Kesehatan Andalas, 9(1S), 74-81. https://doi.org/10.25077/jka.v9i1s.1158

Ismail, N. S. B., \& Sharif, Z. B. (2017). The comparison between listening to Surah Al-Mulk and Surah Al-Hasyr using EEG. Proceedings - 2016 IEEE International Conference on Automatic Control and Intelligent Systems, I2CACIS 2016, October, 28-33. https://doi.org/10.1109/I2CACIS.2016.7885284

Kemenkes. (2007). Permenkes No 1109 tahun 2007.

Managheb, M., \& Jafari, G. (2014). The Musabbihat Suras from the Rhetoric's Point of View. 36-37.

Mao, Y., Zhang, N., Liu, J., Zhu, B., He, R., \& Wang, X. (2019). A systematic review of depression and anxiety in medical students in China. BMC Medical Education, 19(1), 1-13. https://doi.org/10.1186/s12909-019-1744-2

Nakhavali, F., \& Seyyedi, H. (2013). A Research on "Rhythm \& Music" in the Qur'an. June 2013. https://doi.org/10.5296/ijl.v5i3.3898 
Nurrezki, S., \& Irawan, R. (2020). Hubungan Stres, Cemas, dan Depresi dengan Kejadian Migrain pada Mahasiswa Kedokteran di Jakarta. 19(1), 1-7.

Rector, N. A., Bourdeau, D., Kitchen, K., \& Massiah, L. J. (2011). Anxiety Disorders an Information Guide.

Rosmarin, D. H., \& Leidl, B. (2020). Spirituality, religion, and anxiety disorders. In Handbook of Spirituality, Religion, and Mental Health. INC. https://doi.org/10.1016/b978-0-12-816766-3.00003-3

Sadock, B. J., Sadock, V. A., \& Ruiz, P. (2007). Synopsis of Psychiatry (eleventh).

Sari, C. F., Pertiwi, H., Indraswari, D. A., \& Bakhtiar, Y. (2019). The Effect of Listening to the Quran Surah Al-Mulk with Translation on Anxiety and Sleep Quality in Medical Students. Front. Pharmacol. Conference Abstract: International Conference on Drug Discovery and Translational Medicine 2018 (ICDDTM '18) "Seizing Opportunities and Addressing Challenges of Precision Medicine." https://doi.org/10.3389/conf.fphar.2019.63.00006

Shekha, M. S., Hassan, A. O., \& Othman, S. A. (2013). Effects of Quran Listening and Music on Electroencephalogram Brain Waves. J. Exp. Biol, 9(1), 1-7.

Wahyuddin, \& Saifulloh, M. (2013). Ulum Al-Quran, Sejarah dan Perkembangannya. Jurnal Sosial Humaniora, 6.

Wijaya, A. A., Sugiharto, H., \& Zulkarnain, M. (2019). Hubungan Kecemasan dengan Nyeri Kepala Tipe Tegang pada Mahasiswa Program Studi Pendidikan Dokter Fakultas Kedokteran Universitas Sriwijaya Angkatan 2013. Sriwijaya Journal of Medicine, 2(1), 223-229. https://doi.org/10.32539/sjm.v2i1.46 